\title{
Essential oils of leaves of Piper species display larvicidal activity against the dengue vector, Aedes aegypti (Diptera: Culicidae)
}

\begin{abstract}
SANTANA HT.1; TRINDADE FTT..$^{2,3}$; STABELI RG. ${ }^{3,4}$; SILVA AAE..$^{2,3^{*}}$; MILITÃO, JSLT. ${ }^{1}$; FACUNDO VA. ${ }^{1}$ 'Laboratório de Pesquisas Químicas em Produtos Naturais (LQPN), Departamento de Química, Universidade Federal de Rondônia (UNIR), Campus Universitário José Ribeiro Filho - BR 364, km 9,5 s/n', Porto Velho, $R O$, Brasil; 'Laboratório de Bioecologia de Insetos (LABEIN), Departamento de Biologia, Universidade Federal de Rondônia (UNIR), Campus Universitário José Ribeiro Filho - BR 364, km 9,5 s/nº, Porto Velho, RO, Brasil; ${ }^{3}$ Fundação Oswaldo Cruz Rondônia (FIOCRUZ RO), Rua da Beira $n^{\circ} 7671$, Bairro Lagoa, Porto Velho, RO, Brasil, CEP 76.812-245. *alealsil@unir.br; ${ }^{4}$ Centro de Estudos de Biomoléculas Aplicadas a Saúde (CEBIO), Departamento de Medicina, Universidade Federal de Rondônia (UNIR), Campus Universitário José Ribeiro Filho - BR 364, km 9,5 s/no, Porto Velho, RO, Brasil
\end{abstract}

\begin{abstract}
The mosquito Aedes aegypti is the vector of the dengue virus, an endemic arbovirus from tropical and subtropical regions of the world. The increasing resistance of mosquitoes to commercial insecticides impairs regular control programs; therefore, chemical prospecting originating from the Amazonian flora is promising for potential new insecticides. Several Piper species are, notably, rich in phenylpropanoids and terpenoids, substances with proven insecticidal activity. The composition and the larvicidal activity of three Piper species against $A$. aegypti were evaluated. Essential oils were extracted by hydrodistillation in a modified Clevenger apparatus and analyzed by GC/MS. The major components found in Piper arboreum were germacrene D (31.83\%) and bicyclogermacrene (21.40\%); in Piper marginatum: (E)-methyl isoeugenol (27.08\%), (E)-anethole (23.98\%) and (Z)-methyl isoeugenol (12.01\%); and in Piper aduncum: (E)-isocroweacin $(29.52 \%)$ and apiole $(28.62 \%)$ and elemicin $(7.82 \%)$. Essential oils from the Piperaceae species studied resulted in Lethal Concentrations $\left(\mathrm{LC}_{50}\right)$ of $34-55 \mathrm{ppm}$, while $\mathrm{LC}_{90}$ was higher than $100 \mathrm{ppm}$, except for $P$. marginatum (85 ppm).
\end{abstract}

Key words: Vector control; Essential oil; Piperaceae; Aedes aegypti.

RESUMO: Óleo essencial da folha de espécies de Piper exibem atividade larvicida contra o vetor da dengue Aedes aegypti (Diptera: Culicidae). O mosquito Aedes aegypti é o vetor do vírus da dengue, um arbovírus endêmico em regiões tropicais e subtropicais do mundo. A crescente resistência dos mosquitos aos inseticidas comerciais prejudica programas regulares de controle, portanto, a prospecção química proveniente da flora amazônica surge como alternativa promissora para novos inseticidas. Várias espécies de Piper são notavelmente ricas em fenilpropanóides e terpenóides, substâncias com atividade inseticida comprovada. A composição e atividade larvicida de três espécies de Piper sobre $A$. aegypti foi avaliada. Os óleos essenciais foram extraídos por hidrodestilação em Clevenger modificado e analisado por GC/MS. Os principais componentes encontrados em Piper arboreum foram germacreno D (31,83\%) e biciclogermacreno (21,40\%); Piper marginatum: (E)-metilo de isoeugenol $(27,08 \%)$, (E)-anetole (23,98\%) e (Z)- methyl isoeugenol (12,01\%), e Piper aduncum: (E)-Isocroweacin $(29,52 \%)$, apiol $(28,62 \%)$ e elemicin $(7,82 \%)$. Os óleos essenciais a partir das espécies de Piperaceae estudadas resultou em concentrações letais $\left(\mathrm{CL}_{50}\right), 34-55 \mathrm{ppm}$, enquanto que $\mathrm{CL}_{90}$ foi superior a 100 ppm, com excepção para P. marginatum (85 ppm).

Palavras-chave: Controle Vetorial; Óleo Essencial; Piperaceae; Aedes aegypti.

\section{INTRODUCTION}

Mosquitoes are important vectors of diseases, such as dengue, that stands out as reemerging disease and public health concern worldwide, affecting mostly poor, urban populations; and also a leading cause of hospital admissions in several countries. Dengue incidence has increased about 30 times over the last 50 years and $50-100$ million infections annually are estimated in more 
than 100 endemic countries, placing almost half the world's population at risk (Who, 2005).

Although, most patients are asymptomatic, subsequent infections with different viruses serotypes may result in hemorrhagic fever with high mortality. In the Latin America, Brazil stands up with $98.5 \%$ of cases, and the highest mortality rate (Who, 2009 and 2010).

Dengue is considered the most important viral disease transmitted and disseminated by arthropods worldwide. The mosquito vector, Aedes aegypti, can be found in all Brazilian states, and dengue outbreaks are often reported (Who, 1997; Who, 2002; MS, 2009).

Chemical control of $A$. aegypti is a challenging issue and dengue outbreaks have repeatedly occurred in Brazil over the last 10 years since this vector species is resistant to insecticides such as organochlorines, organophosphates and onset of resistance to pyrethroids (Tauil, 2006). Besides toxicity, resistance reported in several areas under continuous application of insecticides is also an important issue and alternatives to conventional chemical control based on natural products from plants, including essential oils, stands as a potential source for new molecules for mosquito control. The genus Piper stands out as a source of active principles derived from plants has been described as antimicrobial and insecticidal (Bergo, et al. 2005).

Essential oils of many Brazilian plants display larvicidal activity, e.g., Ocimum americanum, Ocimum gratissimum (Cavalcanti, et al. 2004), Croton zehntneri (Morais, et al. 2006), including Piper species (Morais, et al. 2007), therefore, in the present study, essential oils of three Piper species commonly found in Amazon region, Brazil were tested as larvicides against the dengue vector, $A$. aegypti.

\section{MATERIAL AND METHODS}

\section{Plant material}

Leaves of three different species of Piperaceae: $P$. marginatum Jacq. (pimenta-domato), $P$. arboretum Aubl. (jaborandi-pimenta) and $P$. aduncum Vell. (pimenta-de-macaco) were collected at different areas of the State of Rondonia, Western Amazon, Brazil. Piper species were identified by Dr. J. Gomes from INPA herbarium (Instituto Nacional de Pesquisa da Amazônia) and voucher specimens were deposited under the identification numbers: 216630 for $P$. marginatum, 226856 for $P$. arboretum and 211711 for $P$. aduncum.

\section{GC and GC-MS}

Fresh leaves of each plant were steam distilled in a Clevenger type apparatus and the oils $(1 \mathrm{~mL})$ analyzed by GC using a Varian CP-3800 gas chromatograph coupled to a computer equipped with a STAR WORKSTATION. The instrument operates at the following conditions: equipped with a fused silica $30 \mathrm{~m}$ (CP-Sil 8CB, Varian) capillary column with an internal diameter of $0.25 \mathrm{~mm}$ and a film thickness of $0.25 \mathrm{~mm}$; the hydrogen carrier gas had a delivery rate of $1.5 \mathrm{ml} / \mathrm{min}$ (controlled constant flow); a capillary injector operating at $250^{\circ} \mathrm{C}$ in the split mode (1:100); a flame ionization detector (FID) running at $250{ }^{\circ} \mathrm{C}$; the oven temperature programming was 35 ${ }^{\circ} \mathrm{C}$ during injection, and then increased from 35 to $180{ }^{\circ} \mathrm{C}$ at the rate of $4{ }^{\circ} \mathrm{C} / \mathrm{min}$, increased again until a final temperature of $280{ }^{\circ} \mathrm{C}$ at a rate of $17^{\circ} \mathrm{C} / \mathrm{min}$, and at $280^{\circ} \mathrm{C}$ for $10 \mathrm{~min}$.

GC-MS was performed on a Hewlett Packard 5971 instrument employing the following conditions: column: dimethylpolysiloxane DB-1 coated fused silica capillary column (30 m x 0.25 $\mathrm{mm})$; carrier gas: $\mathrm{He}(1 \mathrm{~mL} / \mathrm{min})$; injector temperature was $250^{\circ} \mathrm{C}$ and the detector temperature $200^{\circ} \mathrm{C}$. The column temperature programming was $35-180^{\circ} \mathrm{C}$ at $4^{\circ} \mathrm{C} /$ min then $180-250^{\circ} \mathrm{C}$ at $10^{\circ} \mathrm{C} / \mathrm{min}$; mass spectra: electron impact $70 \mathrm{eV}$ (Adams 2001). Compounds were identified by their GC retention time relative to known compounds and by comparison of mass spectra with those present in the computer data bank (National Institute for Standard Technology e NIST and 62,235 compounds) and published spectra (Stenhagen, 1974).

\section{Mosquito collection and breeding}

The eggs of Aedes aegypti were collected using ovitraps, i.e., black plastic pots filled with tap water and a wooden paddle, placed in houses found with adult $A$. aegypti in the municipality of Porto Velho - RO (08 44' 11,40"S, 63 53'45,34"W). The ovitraps were removed three days after installation and wooden paddles were analyzed in the laboratory for the presence of $A$. aegypti eggs and placed in plastic trays filled with $1 \mathrm{~L}$ distillated water. After hatching, the larvae were kept under laboratory conditions $\left(28{ }^{\circ} \mathrm{C}, 80 \% \mathrm{RU}\right.$ and $12 \mathrm{~h}$ photoperiod) and fed with grinded dog food pellets. Pupae were transferred to plastic cages and mosquitoes were fed with sucrose $10 \%$ and blood fed on rabbits for egg production. Eggs were collected introducing beaker containing filter paper and distilled water. Third to fouth instar larvae were used in the larvicidal assays.

\section{Larvicidal bioassay}

Five concentrations $(10,50,100,250$ and $500 \mathrm{ppm}$ ) of the essential oils were used based on (Morais, et al. 2007). Batches of 25 larvae of $3^{\circ}-4^{\circ}$ instar for each concentration were tested with four replicates and included a control $(1 \mathrm{ml}$ of

Rev. Bras. PI. Med., Campinas, v.17, n.1, p.105-111, 2015. 
DMSO diluted in $100 \mathrm{ml}$ of water). Larval mortality in intervals of $24 \mathrm{~h}$ and $48 \mathrm{~h}$ was recorded for LC (Lethal Concentration) calculation using Probit Analysis (Minitab 14.1; Minitab Inc). All experiments were repeated three times in different periods (Who, 2005).

The effect of different essential oil of Piper and concentration on larval mortality was analyzed using Two Way Anova using SigmaStat 2.0 (SPSS, Inc).

\section{RESULTS AND DISCUSSION}

A total of 40 volatile constituents were identified, accounting for $98.31-99.79 \%$ of the chemical composition of the correspondent oils. The essential oils of $P$. marginatum and $P$. aduncum had similar percentages of the main terpenoid classes, but differed significantly from a qualitative point of view. The essential oils of $P$. marginatum and $P$. aduncum were characterized mostly by phenylpropanoids: 75.05 and $75.19 \%$, respectively, while sesquiterpene hydrocarbons composed up to $95.21 \%$ of $P$. arboreum oil (Table 1 ).

The major phenylpropanoids in $P$. marginatum were $(E)$-methyl-isoeugenol (27.08\%), $(E)$-anethol $(23.98 \%)$, (Z)-methyl-isoeugenol (1.01\%), and (Z)-anethol (7.9\%); P. aduncum: $(E)$ isocroweacin (29.52\%), apiole (28.62\%) and elemicin (7.82\%), and major sesquiterpenes in P. arboreum were germacreneD $(31.83 \%)$, biciclogermacrene $(21.40 \%)$ and $(E)$-caryophyllene (10.88\%) (Table 1).

The phenylpropanoid anethol, a major component of $P$. marginatum, was also found in high percentage in $P$. marginatum chemotype V (Craveiro, et al. 1976) essential oil, Pimpinella anisum (Erler, et al. 2006), Illicium verum (Lima, et al. 2008), Croton zenhtneri (Santos, et al. 2001).

Santos et al. (2001) analyzed essential oils of 10 Piperaceae species from the Brazilian Atlantic Forest and found that the most frequently identified compounds were sesquiterpenes, differently from $P$. marginatum and $P$. aduncum in the present work, but similar to $P$. arboreum, except for biciclogermacrene. These authors also related $(E)$-caryophyllene and germacrene $D$ as the most common sesquiterpenes identified, also found in lower percentages in the essential oils from leaves of Piper lanceaefolium from Costa Rica (Mundina, et al. 2001).

Cruz et al. (2011) found great diversity of the chemical composition of the essential oils from 15 Piper species from Guatemala and identified $\beta$-caryophyllene in all species, germacreneD in 11 and biciclogermacrene only in Piper sempervirens.

Besides the major components found here in the oil of $P$. aduncum, Maia et al. (1998) and Fazolin et al. (2007) also related other major components for the same plant species. Differences in oil components probably resulted from different environmental conditions for plant development (Simas, et al. 2004).

Aedes aegypti larvae were exposed to the essential oil of the studied plants all died after a few hours exposure only when exposed to 500 and 250 ppm. But larval mortality decreased significantly $(F=312.66 ; P<0.001)$ in lower oil concentrations. The oil of Piper marginatum, usually, was the most effective against larvae (Table 2).

Piper marginatum oil had the lowest $\mathrm{CL}_{50}$ and $\mathrm{CL}_{90}$ values and significantly $(\mathrm{F}=26.09 ; \mathrm{P}<0.001)$ caused higher larval mortality at 50 and 100 ppm related to the other species (Table 2). Piper aduncum and $P$. arboreum had higher $\mathrm{CL}_{50}$ values (Table 3 ) and did not differed significantly in the mean mortality caused to $A$. aegypti larvae (Table 2 ).

Interestingly, Autran et al. (2008) evaluated the larvicidal properties of the essential oils of different parts of $P$. marginatum against $A$. aegypti and reported a similar larvicidal activity for the essential oil extracted from leaves. But, majoritarian oil components, i.e, (Z)-azarone and patchouli alcohol, were not detected in the present work. Andrade et al. (2008) described seven chemotypes of $P$. marginatum based on the oil components. The present sample from Rondonia State was similar to chemotype V, i.e., high content of $(E)$-anethole, while Autran's was similar to chemotype VII, indicating that, despite of chemical characteristics, larvicidal activity is retained in different $P$. marginatum chemotypes due to other insecticidal molecules.

The presence of anethol in Piper marginatum composition could be responsible to the larvicidal activity because Cheng et al (2004) related a LC $_{50}$ $=42 \mathrm{ppm}$ of this compound to $A$. aegypti, very close the data informed in the present study. Also this phenylpropanoid was highly effective in the control mosquito larvae in other studies, e.g., Aedes aegypti (Chantraine, et al. 1998; Morais, et al. 2006), Ochlerotatus caspius (Knio, et al. 2008) and other insects, e.g., the cockroach Blattella germanica (Chang, et al. 2002), the beetle Zabrotes subfaciatus (Silva and Câmara, 2007). Besides, anethol also repelled Culex pipiens mosquitoes (Lima, et al. 2008) and the aphid Brevicoryne brassicae (Santos, et al. 2001).

Other components present in the oil of $P$. marginatum, e.g., methyl-isoeugenol, possible contributed to the larvicidal activity found in the present work. Park et al. (2007) related that this molecule had nematicidal activity against the pine wood nematode, Bursaphelenchus xylophilus. A similar molecule, methyl-eugenol, also presented 
TABLE 1. Composition (\%) of the leaf oil of Piper marginatum, P. arboreum and $P$. aduncum collected in Rondonia State, Brazil.

\begin{tabular}{|c|c|c|c|c|}
\hline Compound & K.I." & P. marginatum & P. arboreum & P. aduncum \\
\hline$\alpha$-pinene & 939 & 2.46 & - & 1.81 \\
\hline canfene & 954 & 1.02 & - & - \\
\hline$\beta$-pinene & 979 & 2.27 & - & 1.70 \\
\hline$\delta$-carene & 1002 & 4.27 & - & - \\
\hline limonene & 1029 & - & - & 1.43 \\
\hline cis-ocimene & 1037 & - & - & 3.28 \\
\hline trans-ocimene & 1050 & - & - & 7.70 \\
\hline (Z)-anethol & 1253 & 7.90 & - & - \\
\hline$(E)$-anethol & 1285 & 23.98 & - & - \\
\hline safrole & 1287 & - & - & 3.31 \\
\hline$\delta$-elemene & 1338 & - & 3.44 & - \\
\hline$\alpha$-copaene & 1377 & 1.85 & 1.13 & 0.40 \\
\hline$\beta$-bourbonene & 1388 & - & 2.22 & - \\
\hline$\beta$-cubebene & 1389 & - & 0.67 & - \\
\hline$\beta$-elemene & 1391 & 0.95 & 3.63 & - \\
\hline$\beta$-caryophyllene & 1409 & 2.28 & 10.88 & 2.51 \\
\hline$\beta$-curjunene & 1434 & - & 1.73 & - \\
\hline (Z)-methyl-isoeugenol & 1454 & 12.01 & - & - \\
\hline$\alpha$-humulene & 1455 & - & 1.49 & 0.64 \\
\hline aromadendrene- dehydro & 1463 & 4.06 & - & - \\
\hline allo-aromadendrene & 1460 & - & 1.72 & - \\
\hline$\beta$-chamigrene & 1478 & 1.59 & - & - \\
\hline germacreneD & 1485 & - & 31.83 & 2.28 \\
\hline$\beta$-selinene & 1490 & - & 4.23 & - \\
\hline (E)-methyl-isoeugenol & 1492 & 27.08 & - & - \\
\hline biciclogermacrene & 1499 & - & 21.40 & 0.99 \\
\hline germacreneA & 1509 & - & 1.41 & - \\
\hline miristicin & 1519 & - & - & 5.92 \\
\hline elemol & 1550 & 2.51 & - & - \\
\hline ঠ-candinene & 1523 & - & 1.36 & - \\
\hline$(E)$-isocroweacin & 1555 & - & - & 29.52 \\
\hline elemicin & 1557 & 2.41 & - & 7.82 \\
\hline germacreneB & 1561 & - & 8.07 & - \\
\hline isoelemicin & 1570 & 1.67 & - & - \\
\hline caryophyllene oxide & 1583 & - & 1.44 & - \\
\hline globulol & 1585 & - & 0.46 & - \\
\hline viridifloral & 1593 & - & 0.54 & - \\
\hline himachalol & 1650 & - & 1.50 & - \\
\hline a-cadinol & 1654 & - & 0.64 & - \\
\hline apiole & 1678 & - & - & 28.62 \\
\hline \multicolumn{5}{|l|}{ Terpenoid class composition } \\
\hline Monoterpene hydrocarbons & & 10.02 & - & 15.92 \\
\hline Sesquiterpene hydrocarbons & & 10.73 & 95,21 & 6.82 \\
\hline Oxygenated sesquiterpenes & & 2.51 & 4,58 & - \\
\hline Phenylpropanoids & & 75.05 & - & 75.19 \\
\hline Total & & 98.31 & 99,79 & 97.93 \\
\hline
\end{tabular}

'Retention index. The identified constituents are listed in their order of elution from a nonpolar Column.

contact toxicity against the cockroach Periplaneta americana and also larvicidal activity against $A$. aegypti (Morais, et al. 2006).

Piper aduncum also displayed similar insecticidal activity against workers of the fire ant, Solenopsis saevissima (Ngoh, et al. 1998), but the majoritarian compound, dillapiole, has a different methoxy group position in the benzene ring 
TABLE 2. Larval mortality (\%) of Aedes aegypti after 96 hours exposure to the essential oils of different Piper species ( $P$. aduncum, $P$. arboreum and $P$. marginatum)

\begin{tabular}{|c|c|c|c|c|c|c|}
\hline \multirow[b]{2}{*}{ Species } & \multicolumn{4}{|c|}{ Concentrations (ppm) } & \multirow[b]{2}{*}{500} & \multirow[b]{2}{*}{ Mean $( \pm 1,9)$} \\
\hline & $\overline{10}$ & 50 & 100 & 250 & & \\
\hline P. aduncum & $19.0^{b 4}$ & $49.0^{\circ 3}$ & $71.3^{\mathrm{b} 2}$ & $99.3^{1}$ & $100^{1}$ & $56^{\mathrm{b}}$ \\
\hline P. arboreum & $23.6^{\mathrm{a} 4}$ & $38.3^{\mathrm{b3}}$ & $59.3^{\mathrm{b} 2}$ & $98.6^{1}$ & $100^{1}$ & $53^{b}$ \\
\hline P. marginatum & $13.0^{\text {ьз }}$ & $78.0^{\mathrm{a} 2}$ & $99.3^{\mathrm{a} 1}$ & $100^{1}$ & $100^{1}$ & $65^{a}$ \\
\hline Mean $( \pm 2,35)$ & $18^{4}$ & $55^{3}$ & $76^{2}$ & 991 & $100^{1}$ & \\
\hline
\end{tabular}

Two Way Anova (species and concentration) and Student-Newman-Keuls (comparisons). Different letters and number indicate significant differences $(P<0,05)$ in the same columm and row, respectively. No mortality was detected in control groups.

compared to apiole, one of the main compounds found in $P$. aduncum in the present work.

The main component of $P$. arboreum oil, the sesquiterpene germacrene $D$, displayed the highest mosquitocidal activity against Culex quinquefasciatus, Anopheles gambiae and $A$. aegypti (Souto, et al. 2012) and may be related to larvicidal activity of this species to $A$. aegypti since its percentage in $P$. arboreum was 3 times higher than found by Kiran and Devi (2006) in the plant Chloroxylon swietenia.

Interestingly, Piper humaytanum had similar percentage of $\beta$-caryophyllene, one of the main compounds of the essential oil from Piper arboreum, but germacrene $D$ was not detected. This species displayed $\mathrm{LC}_{50}$ to $A$. aegypti three times higher than Piper arboreum in the present study (Table 3).

Hummelbrunner and Isman (2001) related significant synergistic effects of several essential oil compounds on the tobacco cutworm, Spodoptera litura. Therefore, future analysis of single components, e.g., anethol, methyl-isoeugenol and germacrene D from the Piper species studied and potential synergistic or addictive effects among them in the larvicidal activity on $A$. aegypti and also other important mosquito species, e.g, the malaria vector, Anopheles darlingi, may provide new affordable and efficient molecules for chemical control of these insects.

Concluding, the main components found in Piper arboreum were germacrene D $(31.83 \%)$ and bicyclogermacrene (21.40\%); Piper marginatum: (E)-methyl isoeugenol (27.08\%), (E)-anethole $(23.98 \%)$ and $(Z)$ - methyl isoeugenol $(12.01 \%)$ and Piper aduncum (E) - Isocroweacin (29.52\%), apiol $(28.62 \%)$ and elemicin $(7.82 \%)$. Essential oils from the Piperaceae species studied resulted in lethal concentrations (LC50) 34-55 ppm, whereas LC90 was greater than $100 \mathrm{ppm}$, except for $P$. marginatum (85 ppm), the essential oil of this plant that showed the highest larvicidal activity against Aedes aegypti.

\section{CONCLUSIONS}

The main components found in Piper arboreum were germacrene D $(31.83 \%)$ and bicyclogermacrene (21.40\%); Piper marginatum: (E)-methyl isoeugenol (27.08\%), (E)-anethole $(23.98 \%)$ and $(Z)$ - methyl isoeugenol $(12.01 \%)$ and Piper aduncum (E) - Isocroweacin (29.52\%), apiol

TABLE 3. Lethal Concentrations $\left(\mathrm{LC}_{50}\right.$ and $\left.\mathrm{LC}_{90}\right)$ of the essential oils of Piper species on $3^{\circ}-4^{\circ}$ instar larvae of the mosquito Aedes aegypti (Diptera: Culicidae).

\begin{tabular}{ccccccc}
\hline \multicolumn{7}{c}{ Lethal Concentration } \\
(ppm)
\end{tabular}

$\mathrm{PPM}=$ parts per million. Calculated from data mortality from $24-48$ hours

$\mathrm{Cl} 95 \%=$ Confidence Interval. Calculated from data used for lethal concentrations

$\mathrm{SE}=\mathrm{Standard}$ Error. Calculated from mean from data mortality from 24-48 hours

Rev. Bras. PI. Med., Campinas, v.17, n.1, p.105-111, 2015. 
(28.62\%) and elemicin (7.82\%). Essential oils from the Piperaceae species studied resulted in lethal concentrations (LC50) 34-55 ppm, whereas LC90 was greater than $100 \mathrm{ppm}$, except for $P$. marginatum (85 ppm), the essential oil of this plant that showed the highest larvicidal activity against Aedes aegypti.

\section{REFERENCES}

ADAMS, R.P. Identification of Essential Oil Components by Gas Chromatography/Quadrupole Mass Spectroscopy. 3ed. Allured Illinois: New York, NY, USA, Charpter, 2002. 455p.

ANDRADE, E.H.A.; CARREIRA, L.M.M.; SILVA, M.H.L.; SILVA, J.D.; BASTOS, C.N.; SOUSA, P.J.C.; GUIMARÃES, E.F.; MAIA, J.G. Variability in Essential-Oil Composition of Piper marginatum sensu lato. Chemistry \& Biodiversity, v.5, n.1, p.197-208, 2008.

AUTRAN, E.S.; NEVES, I.A.; SILVA, C.S.B.; SANTOS, G.K.N.; CÂMARA, CAG, NAVARRO, D.M.A.F. Chemical composition deterrent and larvicidal activities against Aedes aegypti of oils from Piper marginatum Jacq. (Piperaceae). Bioresource Technology, v.100, n.1, p.2284-2288, 2009.

BERGO, C.L.; MENDONÇA, H.A.; SILVA, M.R. Efeito da época e freqüência de corte de pimenta longa (Piper hispidinervum C. DC.) no rendimento de óleo essencial. Acta amazônica, v.35, n.2, p.111-117, 2005.

CAVALCANTI, E.S.B.; MORAIS, S.M.; LIMA, M.A.A.; SANTANA, E.W.P. Larvicidal activity of essential oils from Brazilian plants against Aedes aegypti L. Memórias Instituto Oswaldo Cruz, v.99, n.5, p.541-544, 2004.

CHANG, K.S.; AHN, Y.J. Fumigant activity of (E)-anethole identified in Illicium verum fruit against Blattella germanica. Pest management science, v.58, n.2, p.161-166, 2002.

CHANTRAINE, J.M.; LAURENT, D.; BALLIVIAN, C.; SAAVEDRA, G.; IBAÑEZ, R. VILASECA, L.A Insecticidal activity of essential oils on Aedes aegypti larvae. Phytotherapy Research, v.12, n.5, p.350-354,1998.

CHENG, S.S.; LIU, J.Y.; TSAI, K.H.; CHEN, W.J.; CHANG, S.T. Chemical composition and mosquito larvicidal activity of essential oils from leaves of different Cinnamomum osmophloeum provenances. Journal of Agricultural of Food Chemistry, v.52, n.14, p.43954400, 2004.

CRAVEIRO, A.A.; MATOS, F.J.A.; ALENCAR, J.W. A simple and inexpensive steam generator for essential oils extraction. Journal of Chemical Education, v.53, n.10, p.652, 1976.

CRUZ, S.M.; CÁCERES, A.; ÁLVAREZ, L.E.; APEL, M.A.; HENRIQUES, A.T. Chemical diversity of essential oils of 15 Piper species from Guatemala. Acta Horticulturae, v.11, n.1, p.964, 2011.

ERLER, F.; ULUG, I.; YALCINKAYA, B. Repellent activity of five essential oils against Culex pipiens. Fitoterapia, v.77, n.7, p.491-494, 2006.

FAZOLIN, M.; ESTRELA, J.L.V.; CATANI, V.; ALÉCIO, M.R.; LIMA, M.S. Propriedade inseticida dos óleos essenciais de Piper hispidinervum C. DC.; Piper aduncum L. e Tanaecium nocturnum (Barb. Rodr.)
Bur. \& K. Shum sobre Tenebrio molitor L.; 1758. Ciências Agrotecnicas, v.31, n.1, p.113-120, 2007. HUMMELBRUNNER, L.A. AND ISMAN, M.B. Acute, Sublethal, Antifeedant, and Synergistic Effects of Monoterpenoid Essential Oil Compounds on the Tobacco Cutworm, Spodoptera litura (Lep., Noctuidae). Journal of Agricultural of Food Chemistry, v. 49, n.2, p.715-720, 2001.

KIRAN, S.R.; BHAVANI, K.; DEVI, P.S.; RAO, B.R.R.; REDDY, K.J. Composition and larvicidal activity of leaves and stem essential oils of Chloroxylon swietenia DC against Aedes aegypti and Anopheles stephensi. Bioresource Technology, v.97, n.18, p.2481-2484, 2006.

KNIO, K.M.; USTA, J.; DAGHER, S.; ZOURNAJIAN, H.; KREYDIYYEH, S. Larvicidal activity of essential oils extracted from commonly used herbs in Lebanon against the seaside mosquito, Ochlerotatus caspius. Bioresource Technology, v.99, n.4, p.763-768, 2008.

LIMA, R.K.; CARDOSO, M.G.; MORAES, J.C.; VIEIRA, S.S.; MELO, B.A. FILGUEIRAS, C.C. Composição dos Óleos Essenciais de Anis-estrelado Illicium verum L. e de Capim-limão Cymbopogon citratus (DC.) Stapf: Avaliação do Efeito Repelente sobre Brevicoryne brassicae (L.) (Hemiptera: Aphididae). BioAssay, v.3, n.1, p.1-6, 2008.

MAIA, J.G.S.; ZOGHBI, M.G.S.; ANDRADE, E.H.A.; SANTOS, A.S.; SILVA, M.L.; LUZ, A.I.R.; BASTOS, C.N. Constituintes of the essential oil of Piper aduncum $L$. growing in the Amazon Region. Flavour and Fragrance Journal, v.13, n.1, 269-272, 1998.

Ministério da Saúde. Dengue no Brasil. Informe epidemiológico 16/2009 Monitoramento CGPNCD.

MORAIS, S.M.; CAVALCANTI, E.S.B.; BERTINI, L.M.; OLIVEIRA, C.L.L.; RODRIGUES, J.R.B.; LEALCARDOSO, J.H. Larvicidal activity of essential oils from Brazilian Croton species against Aedes Aegypti L. Journal of the American Mosquito Control Association, v.22, n.1, p.161-164, 2006.

MORAIS, S.M.; FACUNDO, V.A.; BERTINI, L.M.; CAVALCANTI, E.S.B.; JUNIOR, J.F.A.; FERREIRA, S.A. Chemical composition and larvicidal activity of essential oils from Piper species. Biochemical Systematics and Ecology, v.35, n.10, p.670-675, 2007.

MUNDINA, M.; VILA, R.; TOMI, F.; TOMAS, X.; CICCIO, J.F.; ADZET, T.; CASANOVA, J.; CANIGUERAL, S. Composition and chemical polymorphism of the essential oils from Piper lanceaefolium. Biochemical Systematics and Ecology, v.29, n.7, p.739-748, 2001.

NGOH, S.P.; CHOO, L.E.W.; PANG, F.Y.; HUANG, Y.; KINI, M.R.; HO, S.H. Insecticidal and Repellent Properties of Nine Volatile Constituents of Essential Oils against the American Cockroach, Periplaneta americana (L.). Pesticide Science, v.54, n.3, p.261-268, 1998.

PARK, K.; KIM, J.; LEE, G.; SHIN, S. Nematicidal Activity of Plant Essential Oils and Components From Ajowan (Trachyspermum ammi), Allspice (Pimenta dioica) and Litsea (Litsea cubeba) Essential Oils Against Pine Wood Nematode (Bursaphelenchus Xylophilus). Journal of Nematology, v.39, n.3, p.275-279, 2007.

SANTOS, P.R.D.; MOREIRA, D.L.; GUIMARÃES, E.F.; KAPLAN, M.A.C. Essential oil analysis of 10 Piperaceae species from the Brazilian Atlantic forest.

Rev. Bras. PI. Med., Campinas, v.17, n.1, p.105-111, 2015. 
Phytochemistry, v.58, n.1, p.547-551, 2001.

SILVA, C.G.V.; CÂMARA, C.A.G. Composição química e ação inseticida de óleos essenciais de Croton grewioides (Baill) sobre Zabrotes subfasciatus (Boheman). Journal of Essential Oil Research, v.20, n.1, p.179-182, 2007.

SIMAS, N.K.; LIMA, E.C.; CONCEIÇÃO, S.R.; KUSTER, R.M.; OLIVEIRA FOLHO, A.M. Produtos naturais para o controle da transmissão da dengue- atividade larvicida de Myroxylon balsamum (óleo vermelho) e de terpenóides e fenilpropanóides. Química Nova, v.27, n.1, p.46-49, 2004.

SOUTO, R.N.P.; HARADA, A.Y.; ANDRADE, E.H.A.; MAIA, J.G.S. Insecticidal Activity of Piper Essential Oils from the Amazon Against the Fire Ant Solenopsis saevissima (Smith) (Hymenoptera: Formicidae). Neotropical Entomology, v.41, n.2, p.510-517, 2012.

STENHAGEN, E.; ABRAHAMSON, S.; MACLAFFERTY, F.W. In Registry of Mass Spectral Data. 3ed. J. Wiley \& Sons: New York, NY, USA, 1974. 20p.

TAUIL, P.L. Perspectivas de controle de doenças transmitidas por vetores no Brasil. Revista da Sociedade Brasileira de Medicina Tropical, v.39, n.3, p.275-277, 2006.

WHO- World Health Organization. Dengue and dengue hemorrhagic fever, 2002.

WHO- World Health Organization. Dengue: Guidelines for diagnosis, treatment, prevention and control, 2009.

WHO- World Health Organization. Executive committee of the directing council the regional committee Pan American World Health 120th Meeting CE120/21, 1997.

WHO- World Health Organization. First WHO report on neglected tropical diseases: working to overcome the global impact of neglected tropical diseases, 2010.

WHO- World Health Organization. Guidelines for laboratory and field-testing of mosquito larvicidal, 2005.

WHO- World Health Organization. Handbook for clinical management of dengue, 2012. 